\title{
Jordskcelvet ved Sumatra - seismologisk set
}

Af Tine B. Larsen og Peter Voss, GEUS

Jorden svinger stadig efter det store jordskælv vest for det nordlige Sumatra d. 26. december 2004. Jordskælvet, som netop er blevet opjusteret til 9,3 på Richterskalaen, er det største siden jordskælvet ud for Chiles kyst i 1960, som målte 9,5.

Sumatra-jordskælvet var kraftigt nok til at sætte hele jordkloden i svingninger, og disse svingninger, kaldet egensvingninger, forventes at kunne måles frem til cirka april 2005. Egensvingningerne beskrives nedenfor. Efterskælvene fortsætter ligeledes, og selvom den generelle tendens er færre og mindre jordskælv med tiden, er der stadig perioder med både kraftige og hyppige efterskælv.

\section{Det store jordskælv}

Det store jordskælv fandt sted kl 0:58 UTC, hvilket svarer til kl 1:58 dansk tid og kl 7:58 lokal tid. Rystelserne fra det kraftige jordskælv bredte sig ud gennem jorden og blev hurtigt registreret af de internationale netværk af seismografer. En seismograf er et fintfølende måleinstrument, der er specielt designet til at registrere rystelser fra jordskælv. Allerede efter ca. et kvarter havde amerikanske seismologer en foreløbig lokali-

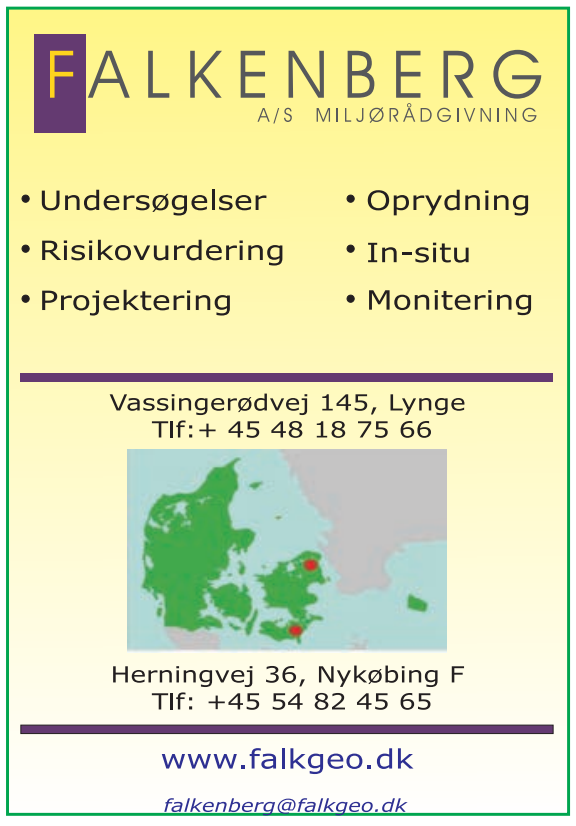

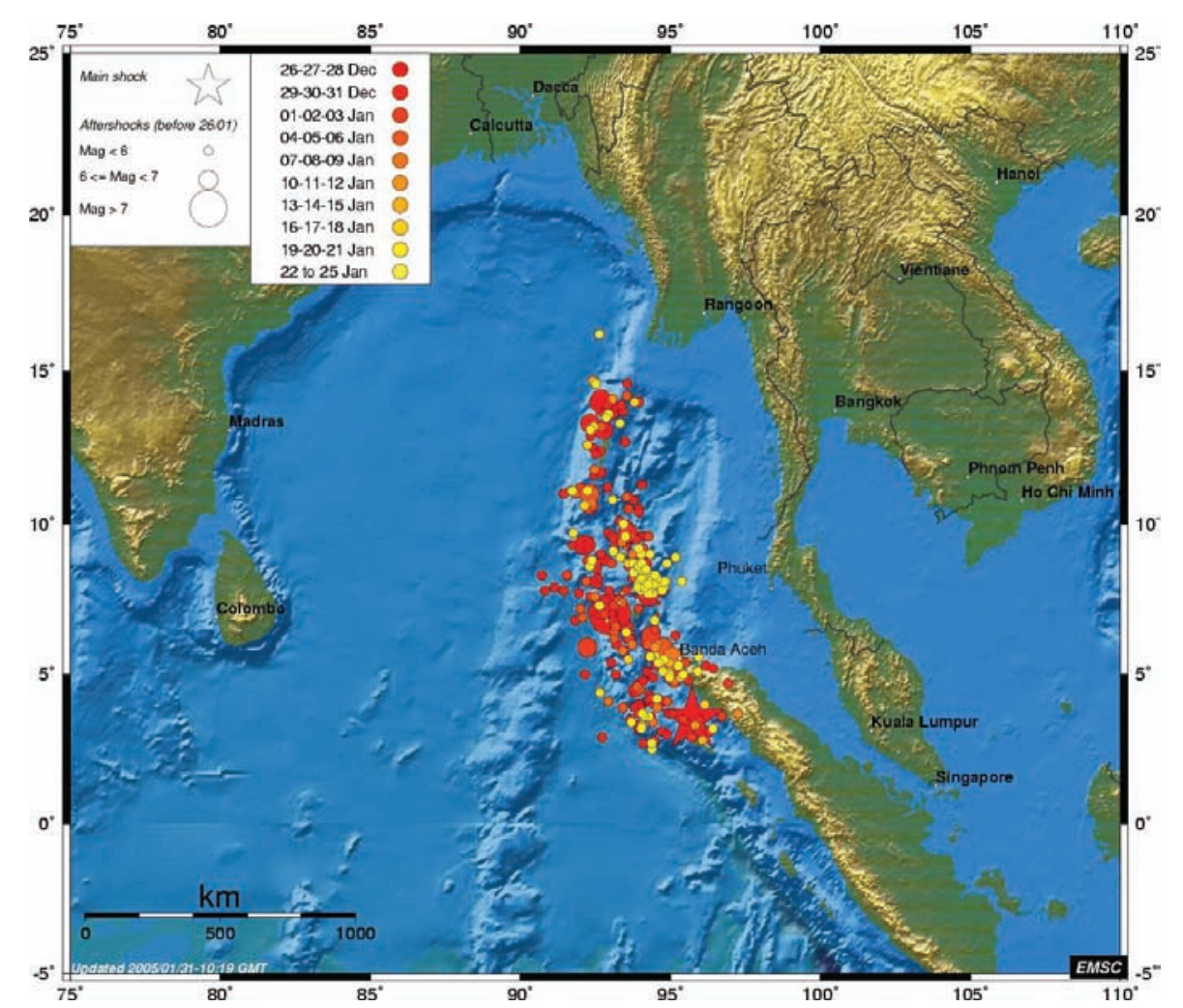

Hovedskclvet (markeret med stjerne) og efterskclv i Det Indiske Ocean registreret gennem en måned. Prikkernes farve viser, hvornår det enkelte efterskcelv har fundet sted, og prikkernes størrelse angiver, hvor store efterskclvene har været.(Kilde: Venligst udlånt af EMSC (European Mediterranean Seismological Center). Aftershocks of Sumatra earthquake relocated by EMSC from 26/12 to 25/01)

sering af jordskælvet, og efter en halv time udsendte de den første bulletin. På det tidspunkt var ingen uden for det berørte område klar over, at der var skabt en tsunami. Efter ca. en time udsendte amerikanerne en advarsel om, at der var fare for at jordskælvet havde skabt en tsunami, men desværre nåede advarslen ikke at gøre nogen nytte.

\section{Tsunami eller ej}

Hvorfor var det så svært at forudsige, at der var skabt en dræbende tsunami? Der eksisterer ikke noget varslingssystem i Det Indiske Ocean, som kan måle tsunamier direkte i havet. Den amerikanske advarsel byggede derfor udelukkende på seismologiske oplysninger. Næsten alle verdens lande har seismografer, der registrerer rystelser fra nære og fjerne jordskælv. Gennem flere generationer er der opbygget systemer med internationale datacentre, hvor data fra de enkelte lande samles og bearbejdes, så hurtigt som det er praktisk muligt. Efter indførelsen af digitale seismografer flyder data frit på tværs af landegrænser, lige så hurtigt som rystelserne fra jordskælv når frem til de enkelte seismografer. Jordskælv kan således lokaliseres meget kort tid efter, de har fundet sted.

Imidlertid er en lokalisering af jordskælvet ikke tilstrækkeligt til at forudsige, om der kan være dannet en tsunami. Det er ikke nok at vide, at jordskælvet har fundet sted under havbunden, selvom det naturligvis er en første forudsætning. Jordskælvet skal også være meget kraftigt, det skal være udløst i den øverste del af jorden, og endelig er det en forudsætning for dannelse af en tsunami, at der har fundet en voldsom vertikal bevægelse sted. Før man kan afgøre det, er det nødvendigt at beregne jordskælvets fokalmekanisme, og det tager længere tid end at beregne epicenteret. Når fokalmekanismen viser sammenpresning, og jordskælvet har fundet sted i et område, hvor en oceanisk lithosfæreplade skyder ned under en anden plade, er risikoen for dannelsen af en tsunami stor. 
Jordskælvets størrelse på Richterskalaen beregnes ud fra hvor stor amplitude rystelserne har på seismograferne. Måling af amplituder er behæftet med stor usikkerhed, og størrelsen på Sumatra-jordskælvet blev ændret mange gange i det første døgn. Således angav den første bulletin jordskælvet til 8,0 på Richterskalaen, og først efter et døgn lå størrelsen på 9,0 fast. Da Richterskalaen er logaritmisk, svarer det til, at jordskælvet udløste 30 gange så meget energi som først antaget. For nylig er jordskælvet blevet opjusteret til 9,3 på Richterskalaen efter nærmere studier af de meget langbølgede svingninger. Beregning af dybden er behæftet med endnu større usikkerhed, og de internationale datacentre er ikke enige om, hvor dybt jordskælvet var. Det europæiske datacenter, EMSC, angiver dybden til $10 \mathrm{~km}$, hvorimod amerikanerne, USGS, beskriver dybden til $30 \mathrm{~km}$. Begge tal er dog tilstrækkelig små, til at jordskælvet karakteriseres som overfladenært.

\section{Efterskælv}

Lithosfærepladerne bevæger sig sjældent helt jævnt i forhold til hinanden, fordi der først skal opbygges tilstrækkeligt store spændinger til at overvinde brudstyrken og gnidningsmodstanden. Pladerne følger fysikkens love og bevæger sig for at opnå en ligevægtstilstand. Et stort jordskælv bringer et område tættere på en ligevægtstilstand, men følges normalt af en række efterskælv, der fungerer som finjustering. Den første måned efter 2. juledag har der været efterskælv hver eneste dag, og stort set hver dag har mindst et af efterskælvene været kraftigt nok til at man må formode, at det har kunnet mærkes. Ingen af efterskælvene har forårsaget tsunamier. Siden ca. d. 26/1 har den geografiske fordeling af efterskælv ændret sig, således at de nu hovedsagelig finder sted under Nicobarerne.

\section{Kendt jordskælvszone}

Underskydningszonen vest for Sumatra hører til blandt jordens mest aktive jordskælvszoner. Den indiske plade presses ned under

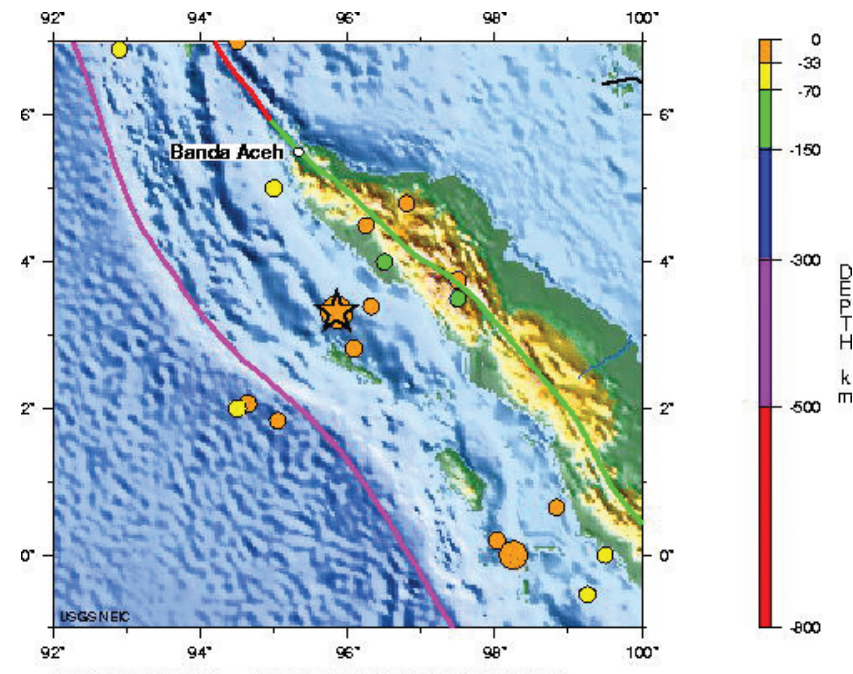

OFF W COAST OF NORTHERN SUMATRA

2004122600.58 .53 UTC 3.32N 95.85E Depth: 30.0 km. Magnitude: 9.0

Magnitude 7 and Greater Earthquakes Since 1900

Major Tectonic Boundaries: Subduction Zones -purple, Aidges -red and Transform Faults -green

USGS National Earthquake Intomation Center
Området vest for Sumatra rammes jæunligt af store jordskcelv. Jordskcelvet $d$. 26/12 2004 er markeret med en stjerne. Prikkerne viser alle jordskcelv i området på 7,0 på Richterskalaen og derover siden 1900. Prikkernes farve viser jordskcelvets dybde. Kun de overfladencere jordskcelv har potentiale til at generere tsunamier. (Kilde : Venligst udlånt af U.S. Geological Survey, National Earthquake Information Center) den burmesiske mikroplade med jævnlige jordskælv til følge. Kraftige jordskælv, som ligger over 7 på Richterskalaen, udløses i Banda Aceh-området i gennemsnit mindst een gang hvert 10. år, mens tsunamier forekommer meget sjældent. De helt store destruktive jordskælv kendes også fra området, omend de heldigvis forekommer meget sjældent. En gruppe amerikanske og indonesiske forskere havde allerede inden d. 26/12 2004 iværksat en undersøgelse af paleoseismiciteten, dvs. jordskælvsaktiviteten langt tilbage i tid, i området vest for Sumatra. Sieh et al. har studeret vækstmønstre i koralrev og har benyttet U-Th datering til at kortlægge den vertikale deformation (hævning) forbundet med store jordskælv. Resultatet er noget overraskende.

Et meget stort jordskælv får ifølge de paleoseismiske undersøgelser ikke altid udløst hovedparten af de opbyggede spændinger. Koralrevene afslører, at gennem de sidste ca. 1.000 år har gigantiske jordskælv rystet ud for Sumatra med ca. 230 års mel- lemrum. Mindst tre af disse jordskælv har været den ene halvdel af et par, der optræder med nogle få årtier imellem. Det seneste store jordskælvspar var i hhv. 1797 og 1833, og de to jordskælv er blevet bestemt til 8,4 og 8,7 på Richterskalaen. Da disse historiske jordskælv medførte betragtelig vertikal uplift af havbunden, er der grund til at formode, at de også har genereret tsunamier. Selvom store jordskælv ved Sumatra tilbage i historien flere gange har optrådt i par, kan vi ikke umiddelbart konkludere, at det seneste store jordskælv vil blive fulgt af et tilsvarende destruktivt jordskælv inden for de næste få årtier. Jordskælv er uforudsigelige. Samtidig bør man dog være forberedt på, at det ikke er sikkert, at der går flere hundrede år, før området igen rammes af et gigantisk jordskælv.

\section{Registreres i Danmark}

Jordskælvet blev registreret af de internationale netværk af seismografer lige så hurtigt som rystelserne bredte sig gennem jorden. De første rystelser nåede de danske seismo-

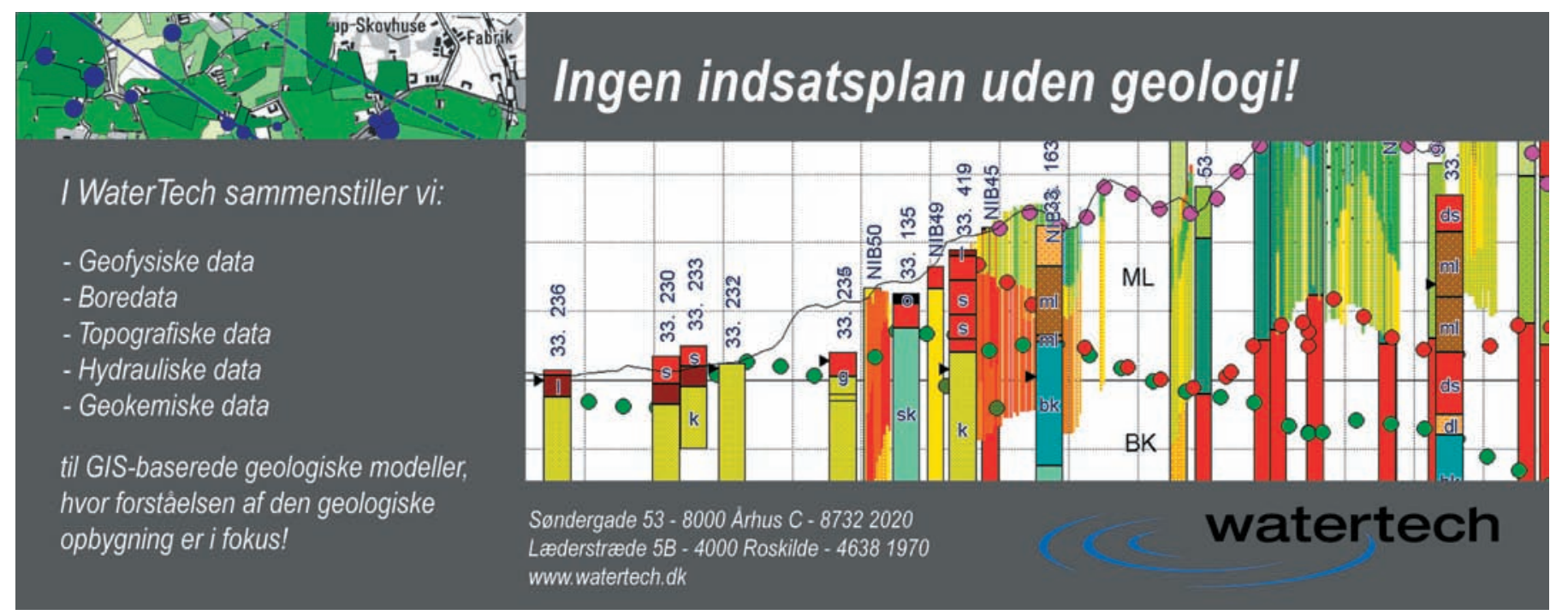


grafer ca. 13 minutter efter jordskælvet. Den største rystelse nåede Danmark knap en time efter jordskælvet, hvor jorden i Danmark hævede og sænkede sig i alt $4 \mathrm{~mm}$ over en periode på 20 sekunder. En så langsom rystelse kan dog ikke mærkes af mennesker.

De kraftige rystelser fra jordskælvet løb flere gange rundt om jorden i timerne efter jordskælvet. Rayleigh-bølger løber langs jordens overflade og har meget lange bølgelængder, så de taber kun energien langsomt. Samtidig er det den type jordskælvsbølge, der giver den største vertikale forskydning. Det er derfor nemt at identificere en Rayleigh-bølge på et seismogram.

I takt med at signalerne fra de cirkulerende bølger bliver svagere og svagere, bliver det tilsvarende sværere at identificere signalet, hvis man kun har nogle få målepunkter, som ligger tæt på hinanden. Tager man derimod seismogrammer fra målepunkter fordelt over hele kloden og ordner dem efter afstand til epicenteret, vil bølgerne træde tydeligere frem som linjer ned over seismogrammerne.

Rayleigh-bølgerne nummereres efter, hvor mange gange de har været rundt om jorden, og hvilken vej de har løbet. Rayleighbølgen, som har løbet den korteste vej fra epicenteret til målepunktet, kaldes $\mathrm{R}_{1}$. Rayleigh-bølgen som har rejst den andenog længere - vej rundt om jorden kaldes $R_{2}$. Når $R_{1}$-bølgen tager sin anden tur rundt om jorden, kommer den til at hedde $\mathrm{R}_{3}$, etc. På de danske seismografer er $\mathrm{R}_{1}$-bølgen meget tydelig, mens $\mathrm{R}_{2}$-bølgen ikke kan identificeres. Til gengæld dukker $\mathrm{R}_{3}$-bølgen nogenlunde klart frem i Danmark ca. tre en halv time efter jordskælvet.

\section{Ringer som en klokke}

Meget kraftige jordskælv sætter gang i Jordens egensvingninger, hvor hele Jorden ringer som en klokke. Kun jordskælv som er større end 6,5 på Richter-skalen genererer målbare egensvingninger. Egensvingningerne er en form for stående bølger, der kan opstå, fordi Jordens udstrækning ikke er uendelig. Bølger, der bevæger sig i forskellige

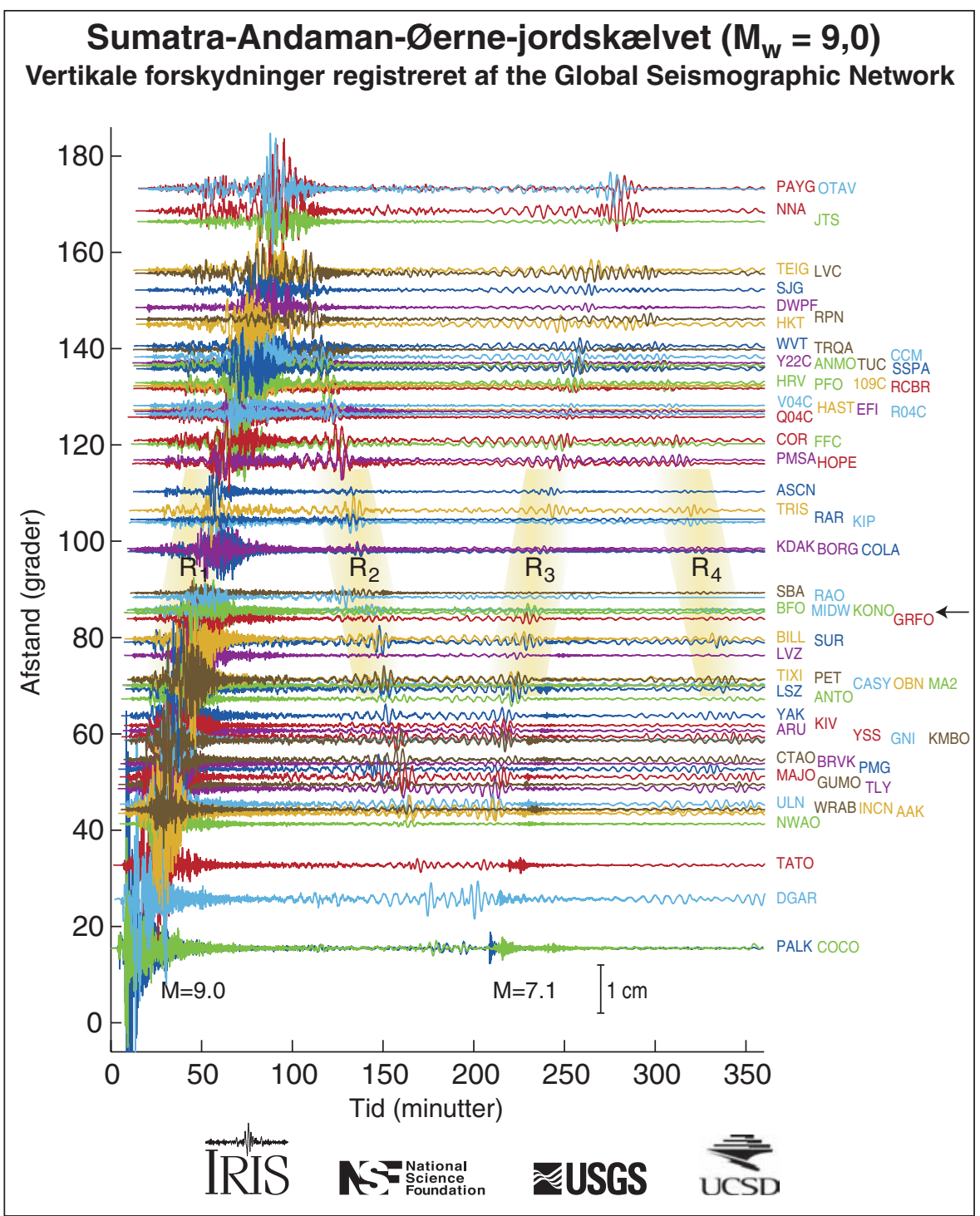

Seismogrammer der viser, at store jordskcelvsbølger har cirkuleret flere gange rundt om jorden $i$ timerne efter jordskclvet. Hver linje på figuren er et seismogram. Seismogrammerne er ordnet efter afstand til epicenteret, og de små koder i højre side angiver navnet på de anvendte målestationer. Der er ikke danske data på figuren, men en lille pil viser, i hvilken afstand Danmark ligger fra epicenteret. GRFO er en tysk målestation. (Kilde: Venligst udlånt af Richard Aster, New Mexico Institute of Mining and Technology, USA, and the IRIS Consortium)

retninger rundt om Jorden, interfererer med hinanden, således at bestemte svingningsfrekvenser bliver kraftigt forstærket i det meget lavfrekvente område. Den mest lavfrekven- te egensvingning kaldes ${ }_{0} \mathrm{~S}_{2}$ (figuren øverst næste side). Den har tilnavnet "football mode", fordijordkloden skiftevis bliver strakt ud og får form som en amerikansk "foot-

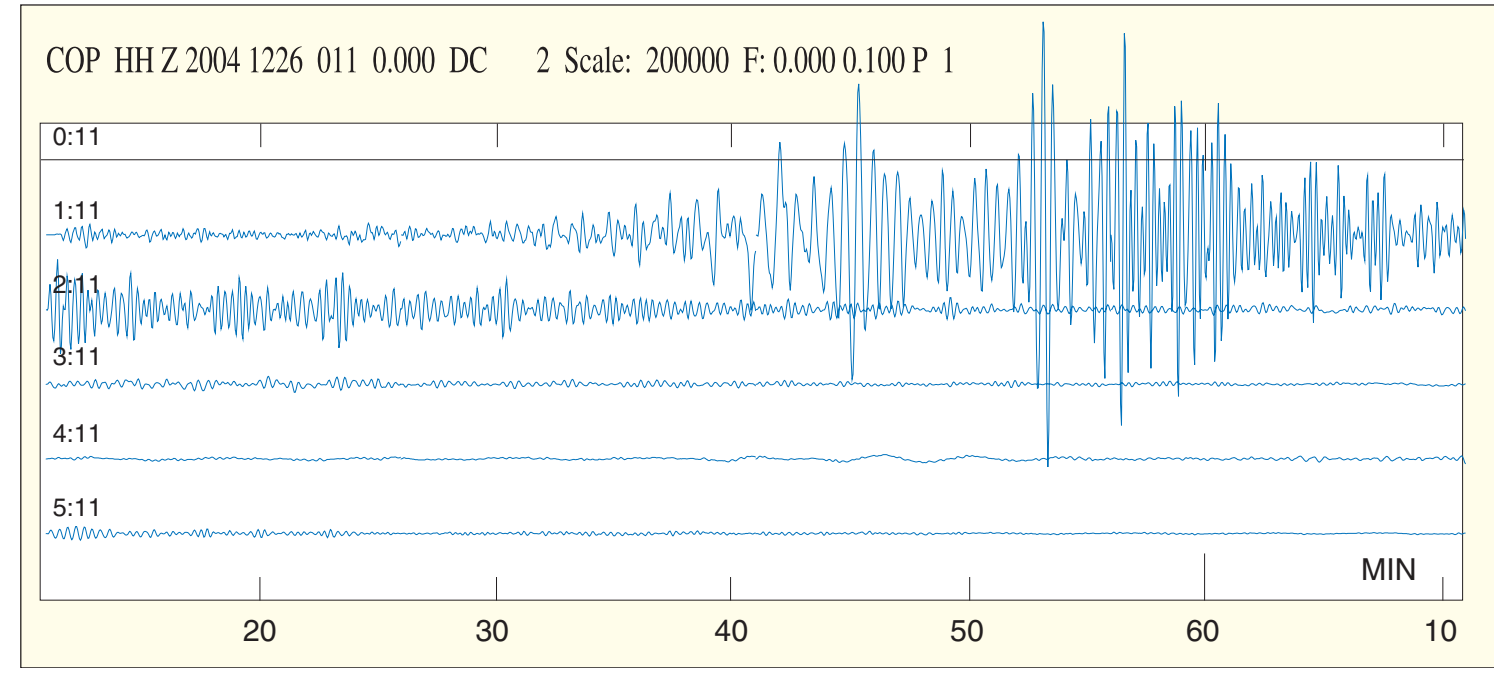

Udsnit af et dansk seismogram fra målestationen i København der viser den vertikale forskydning. Hver linje er een times registrering. Den første rystelse ses kort efter kl 1:11 UTC. Ca. en halv time senere ankommer den første af de store Rayleigh-bølger, også kaldet $R_{1}$. (Grafik: forfatterne) 


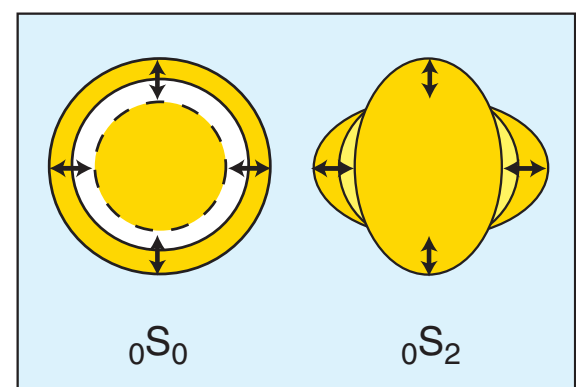

Nogle af jordens egensvingninger, skematisk set. ${ }_{0} S_{0}$ kaldes for "breathing mode", fordi hele jordkloden skiftevis bliver presset sammen og udviddet. $S_{2}$ kaldes for "football mode", fordi jordkloden minder om en amerikansk fodbold, når den skiftevis presses sammen på den ene og den anden led. Fodboldens orientering i forhold til de geografiske poler afhæenger af, hvor på kloden jordskcelvet fandt sted. (Grafik: UVH)

ball”, og derefter bliver mast sammen. ${ }_{0} \mathrm{~S}_{2}$ svinger meget langsomt med en periode på hele 53,9 minutter. Svingningsperioden er den tid, det tager at gennemføre een svingning.

Den mest sejlivede af egensvingningerne hedder $\mathrm{S}_{0}$ med tilnavnet "breathing mode", fordi det er, som om jorden trækker vejret. Hele jordkloden bliver skiftevis presset sammen og udvidet. Denne svingning, som har en periode på 20,5 minutter, taber meget lidt energi og vil formodentlig kunne måles helt til april 2005.

Egensvingningen har dog kun en amplitude på 0,1 mm for de størstes vedkommende, så man måler egensvingningerne ved at lave frekvensanalyse på flere dages data. Ved at lægge fx tre dages registreringer sam-

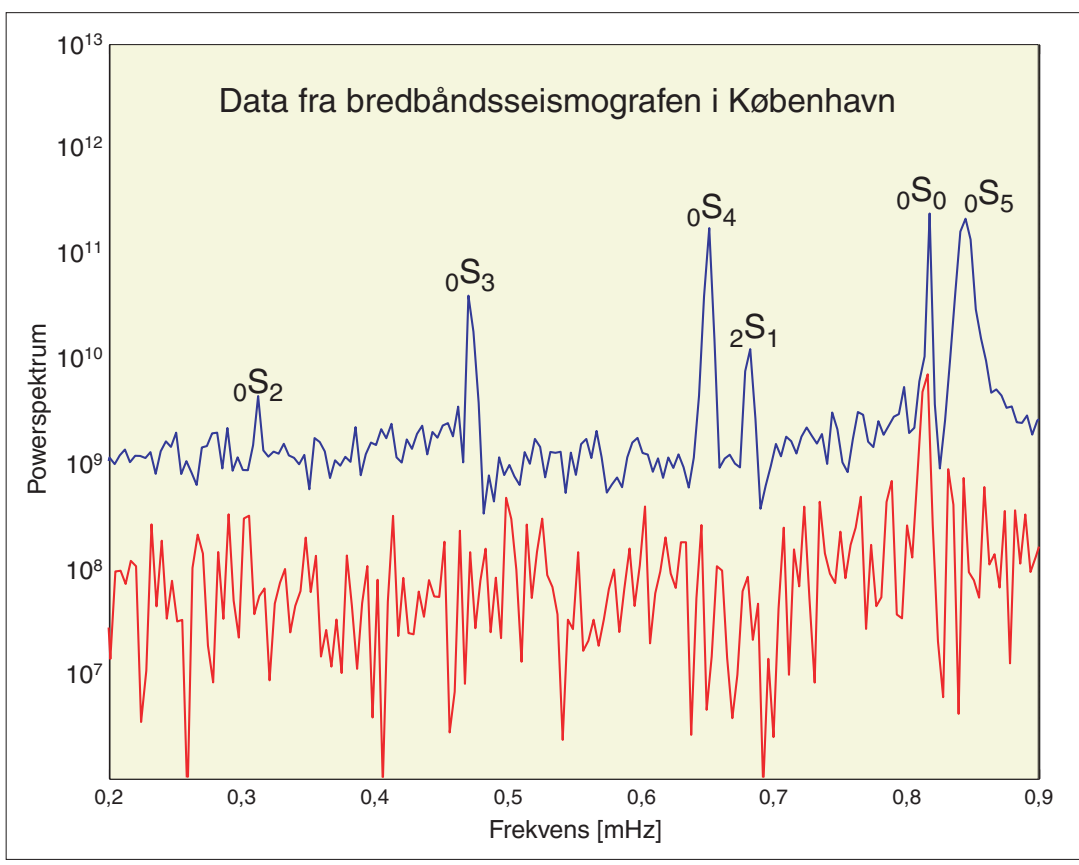

Frekvensanalyse afslører, at jordens egensvingninger er sat i gang. Den blå linje viser data fra de første tre dage efter jordskcelvet. Her er mange eksotiske egensvingninger i gang. Den røde linje viser data fra perioden 30/1 - 2/2 2005. De fleste egensvingninger er kommet ned under det målbare, men ${ }_{0} S_{0}$ ringer endnu - og det vil den formodentlig blive ved med i flere måneder. (Grafik: forfatterne)

men og lave et spektrum, kan man se, at der er mere energi ved de frekvenser (perioder), der svarer til egensvingningerne. Efter Sumatra-jordskælvet er der målt 10 gange større amplituder på egensvingningerne end nogensinde før med digitale seismografer. Ved det sidste store jordskælv i Alaska, 1964, brugte man stadig analoge seismografer, hvor registreringerne blev udtegnet på papir.
Referencer:

K. Sieh, D. Natawidjaja, M. Chlieh, J. Galetzka, J.P. Avouac, B. Suwargadi. R.L. Edwards, \& H. Cheng, The giant subduction earthquakes of 1797 and 1833, West Sumatra: Characteristic couplets, uncharacteristic slip, EOS Trans. AGU, 85 (47), Fall Meet. Suppl., Abstract T12B-04, 2004.

\section{Kort nyt}

\section{Diamanter i Mælkevejen?}

Hvis de rette betingelser er til stede, vil der dannes kulstofforbindelser som karbider og grafit i stedet for kiselforbindelser, som fx Jorden, Venus og Mars er dannet af.

Dannelsen af et tykt lag diamanter i en planet kræver dog et meget højt indhold af kulstof eller et meget lavt indhold af ilt, når planeten dannes ud fra en kæmpe roterende gasskive.

Ingen af vores nærmeste naboer i Mælkevejen indeholder et tykt lag af diamanter, men astronomer mener, at de rette betingelser kan have eksisteret i Mælkevejen. Hvis de eksisterer, vil de være dannet tæt på en pulserende stjerne eller tæt på galaksens center, hvor stjernerne indeholder mere kulstof end vores egen sol, fordi de er ældre.

Berlingske/SP

Atmosfære og vand på Jupiter-måne? Billeder fra overfladen af Jupiters måne Europa har givet anledning til spekulationer om vand og vulkansk aktivitet på månen.
Mens nogle billeder fra Europas overflade minder mistænkeligt om billeder af havis på Jorden, kunne andre indikere, at noget af landskabet er dannet ved en serie af vulkanske udbrud.

Viser det sig, at der er vand under det, man tror, er is, kan vandlaget holdes i live af tidevandsenergi. Hvis dette er tilfældet, kan Europa være det eneste sted i solsystemet, ud over Jorden, hvor vand findes i så store mængder.

\section{Aftenposten/SP}

\section{Nordlys over Danmark}

Fredag aften d. 21/1 og natten til d. 22/1 blev himlen over Danmark farvet rød og grøn, da en geomagnetisk sky ramte atmosfæren. Det var efterveerne af et udbrud på solen, som frigjorde energier, som var mange gange større, end hvad hele verdens atomkraftværker kan producere i årevis, der var årsag til fænomenet.

Når et soludbrud sender en partikelsky ud i universet, og den rammer jordens mag- netfelt, flader partikelskyen ud med det samme. Sammenstødet forårsager en vibrering, hvorefter gasserne i jordens atmosfære begynder at gløde.

Disse gasser gløder i forskellige farvenuancer. Kvælstof giver himlen en hvidlilla farve, mens ilt, som rammes i atmosfæren, gløder rødt. De iltmolekyler, der i de højere luftlag befinder sig tættere på jorden og som rammes af de partikler, som har penetreret de øvre luftslag i atmosfæren, farver himlen grøn.

Udover at sende en magnetisk sky mod jorden udløste omtalte solstorm stribevis af protonbyger, hvilket ikke altid er tilfældet ved en solstorm. Disse protonbyger bevæger sig med lysets hastighed og kan være yderst farlige for luftfarten, idet den radioaktive stråling kan beskadige flyvemaskiner og deres passagerer. Protonbygerne er de kraftigste, der har ramt jordens magnetfelt siden 1989.

I modsætning til protonbygerne er nordlys helt ufarligt.

$J P / S L J$ 